\title{
ALTERATIONS AND SPATIAL VARIABILITY OF SOIL FERTILITY IN SUCCESSIVE YEARS UNDER NO TILLAGE SYSTEM ( $\left.{ }^{1}\right)$
}

\author{
MARCIO KOITI CHIBA $\left({ }^{(*}\right)$; SIDNEY ROSA VIEIRA $\left({ }^{2}\right)$; ANTONIO PAZ GONZÁLEZ $\left({ }^{3}\right)$; \\ SONIA CARMELA FALCI DECHEN $\left({ }^{2}\right)$; ISABELLA CLERICI DE MARIA $\left(^{(2)}\right.$
}

\begin{abstract}
This study was carried out in order to assess the spatial variability of some soil properties after adoption of no tillage system (NTS). A 19,200 $\mathrm{m}^{2}$ plot was marked with a $20 \times 20 \mathrm{~m}$ spacing grid. Crop yield and soil attributes, at 0-0.2 m deep layer, were measured in 63 points in 1985, 1987 and 1988. The spatial variability was assessed by semivariogram calculation using geostatistics. Soil base saturation index (BS) was interpolated by kriging and also, using a bivariate geostatistical method, the collocated cokriging (CLCK) using terrain elevation as ancillary data. Although, the coefficient of variation (Cv) for soil organic matter content decreased from 1985 $(20.4 \%)$ to $1988(10.7 \%)$, its mean value increased $32 \%$ in the same period. The soil fertility in 1985 was found to be more diverse (i.e. high $\mathrm{Cv}$ value), providing evidences that the clearing and subsequent no tillage cultivation increased soil homogeneity. Experimental semivariograms were best fitted to a spherical model. The cultivation under NTS improved the spatial continuity of the studied attributes at close distances. The range for most of the semivariograms of soil properties varied between 40 and $90 \mathrm{~m}$. Kriged maps allowed distinguishing small areas with different chemical elements content. The CLCK approach resulted in maps with higher details and smoother contours in comparison to kriging and cokriging.
\end{abstract}

Key words: Geostatistics, kriging, cokriging.

\section{RESUMO}

\section{ALTERAÇÕES E VARIABILIDADE ESPACIAL DA FERTILIDADE DO SOLO EM ANOS SUCESSIVOS SOB SISTEMA PLANTIO DIRETO}

Este trabalho objetivou estudar a variabilidade espacial de alguns atributos do solo após a implantação do sistema plantio direto (SPD). Uma área com $19.200 \mathrm{~m}^{2}$ foi demarcada em uma grade com espaçamento de $20 \times 20 \mathrm{~m}$. A produtividade da cultura da soja e os atributos do solo, na camada de 0-0,2 m de profundidade, foram amostrados em 63 pontos de amostragem, realizadas em 1985, 1987 e 1988. A variabilidade espacial foi estudada utilizando a geoestatística através da análise de semivariogramas. O índice de saturação por bases (V) foi interpolado por krigagem ordinária e adicionalmente, usando métodos geoestatísticos bivariados, como a cokrigagem colocada (CKCL) usando as cotas topográficas como informação auxiliar. Verificou-se uma redução nos coeficientes de variação do conteúdo de matéria orgânica do solo de 1985 (20,4\%) para 1988 (10,8\%) ao mesmo tempo de um aumento de 32\% no seu valor médio. Os dados de fertilidade do solo em 1985 revelaram uma maior variação (maior valor de $\mathrm{Cv}$ ), evidenciando que os cultivos subsequentes sob plantio direto aumentaram a homogeneidade dos atributos do solo. Os semivariogramas experimentais tiveram melhor ajuste ao modelo esférico e a utilização agrícola do solo no SPD aumentou a continuidade espacial das propriedades do solo a curtas distâncias. Os alcances para a maioria dos semivariogramas variaram entre 40 e $90 \mathrm{~m}$, para a maioria das propriedades do solo. Os mapas obtidos por krigagem permitiram delinear pequenas regiões com teores distintos de nutrientes no solo. A CKCL resultou em um mapa mais detalhado e com contornos mais suaves que a krigagem e a cokrigagem.

Palavras-chave: Geoestatística, krigagem, cokrigagem.

(1) Received for publication in August 28, 2008 and accepted in October 23, 2009.

( $\left.{ }^{2}\right)$ Instituto Agronômico, Centro de Solos, Av. Barão de Itapura, 1481 13020-902 Campinas (SP).E-mail: mkchiba@iac.sp.gov.br (*) Corresponding author. sidney@iac.sp.gov.br; dechen@iac.sp.gov.br; icdmaria@iac.sp.gov.br

(3) University of A Coruña, Facultad de Ciências, Campus de A Zapateria -15071. A Coruña, Spain. 


\section{INTRODUCTION}

Mapping and understanding the spatialvariability of soil properties is an important trend in order to improve agricultural practices like site-specific management of fertilization, liming and control of plagues and weeds. Although soil variation is often described by classical statistical methods, it has frequently exhibited spatial dependence (VIEIRA et al., 1981; TRANGMAR et al., 1985). In this case, samples collected close to one another have shown to be more similar than those collected at greater distances. The recognition that the total variability observed is partially random and partially spatially dependent helps to optimize sampling procedures (OLIVER and WEBSTER, 1990). If spatial dependence occurs, then using the semivariogram and a geostatistical interpolation method, values can be obtained optimally for not sampled locations (VIEIRA et al., 1983; VIEIRA, 2000). Geostatistical techniques, including non-parametric models have been further developed in the last years, so that different algorithms producing different error of interpolation are now available (GOOVAERTS, 1997). Although univariate methods like ordinary kriging can produce satisfactory results some multivariate kriging procedures also may be performed. Ordinary cokriging (OCK) and collocated cokriging (CLCK) are two bivariate methods that can be used to estimate a principal variable values using an ancillary information. Generally the ancillary information is easier or cheaper to be sampled than the primary one. On the other hand, a higher sampling density of ancillary information results in the fact of secondary variable estimated near to the primary data location filter the influence of distant ones. To solve this problem in the CLCK just the secondary data collocated with the primary is retained ( $\left.X_{U}, 1992\right)$.

Nevertheless, ordinary kriging is still the most widely used interpolation method (GOOVAERTS, 1997). On the other hand, when a spatial structure pattern is not evidenced, it means that spatial variation is due to heterogeneity at scales smaller than the distance between adjoining sampling points.

The study of spatial variation of soil attributes is important to ameliorate fertility specifically where it is needed and this is the basic concept of site-specific management. The variation over time of soil nutrient status has also been investigated by others. BЕСKETT (1987) pointed out that the temporal variability of soil nutrient status might be similar or even higher than the spatial variability. It was also reported that nutrient content in different types of soils varied with time and space and some have reported statistically significant linear correlations between chemical elements in soil samples collect at same location in successive years (BRENK et al., 1999; HosKINSON et al., 1999). To improve agricultural production with minimum environmental impacts the no tillage system (NTS) has been adopted and it is characterized by growing crops without ploughing in order to reduce soil and water loss (AINA et al., 1991), improving soil physical properties (AlvES et al., 1994) and plant nutrient recycling (DE MARIA and CAstro, 1983, Duiker and BeEgle, 2006). Although the control of erosion is the main reason for no tillage system adoption, its long-term effects on soil chemical properties has caused some concern among researchers. DE MARIA et al. (1999) related significant increases of organic carbon and extractable $\mathrm{P}$ and $\mathrm{K}$ content at 5 $\mathrm{cm}$ depth in an Oxisol cultivated under no tillage, but no positive effects on crop productivity was observed. Similarly DUIKER and BEEGLE (2006) also observed higher values for soil organic matter and extractable $\mathrm{P}$ at the $0-15 \mathrm{~cm}$ soil layer in no tillage in comparison to ploughed treatment. In contrast, Rотн et al. (1991) studying different tillage practices, including no tillage, reported decreased organic carbon content in comparison to soil under forest. However, information on spatial variability of soil chemical properties following shifting tilling system is worldwide scanty (Mapa and Kumaragamage, 1996).

This study aimed to assess the spatial variability of some soil attributes after shifting tillage system and the accuracy of bivariate kriging methods in describing the soil fertility.

\section{MATERIAL AND METHODS}

Physical description of the site. The experiment was carried out at the Central Experimental Center of the Instituto Agronômico, Campinas, State of Sao Paulo, Brazil, located at the coordinates $47^{\circ} 04^{\prime} \mathrm{W}$ and $22^{\circ} 15^{\prime}$ $S$. The soil parent material is constituted mainly by basaltic rocks. This site is located at an upland part of the landscape, at about $630 \mathrm{~m}$ height above sea level, in a rolling topography with a slope ranging from 6 to $10 \%$. The climate is subtropical with a mean annual rainfall of about 1,500 mm with 5-6 wet months (November to March) although between years variability may be rather large. The soil, a Latossolo Vermelho eutroférrico (EMBrapA, 2006); Rhodic Eutrudox (SoIl Survey STAFF, 1994), presented at $0-20 \mathrm{~cm}$ depth layer: $\mathrm{pH}-\mathrm{CaCl}_{2}$ $=4.9$, organic carbon $=43 \mathrm{~g} \mathrm{dm}^{-3}$, available $\mathrm{P}=54 \mathrm{mg}$ $\mathrm{dm}^{-3}, \mathrm{~K}=0.5 \mathrm{cmol}_{(+)} \mathrm{dm}^{-3}, \mathrm{Ca}=2.8 \mathrm{cmol}_{(+)} \mathrm{dm}^{-3}, \mathrm{Mg}=0.9$ $\mathrm{cmol}_{(+)} \mathrm{dm}^{-3}, \mathrm{H}+\mathrm{Al}=4.3 \mathrm{cmol}_{(+)} \mathrm{dm}^{-3}$, cation exchange capacity $(\mathrm{CEC})=8.5 \mathrm{cmol}_{(+)} \mathrm{dm}^{-3}$ and base saturation $(B S)=49 \%$. The soil also presented $575 \mathrm{~g} \mathrm{~kg}^{-1}$ clay, 188 $\mathrm{g} \mathrm{kg}^{-1}$ silt and $237 \mathrm{~g} \mathrm{~kg}^{-1}$ sand in the A horizon $(0-32 \mathrm{~cm})$ and $671 \mathrm{~g} \mathrm{~kg}^{-1}$ clay, $125 \mathrm{~g} \mathrm{~kg}^{-1}$ silt and $204 \mathrm{~g} \mathrm{~kg}^{-1}$ sand in the Bw horizon $(32-300+\mathrm{cm})$.

Crop history. The cropping history of the site was surveyed at least during more than 20 years before starting sampling for present work purposes in 1985. 
Between 1965 and 1975 a third of the field down the slope was cultivated with grapes and the other two thirds were cultivated with annual crops. Afterwards the field was not cultivated for a 10 years period, until 1985. Spontaneous weed vegetation, mainly grasses, was grown after the field was left fallow in 1975.

In early 1985 the remaining vegetation was burnt out, cleared with bulldozer then moldboard, plowed, disk harrowed and finally, in April 1985, cultivated with Crotalaria juncea as green manure, without fertilizer or lime. After the plant flowering, $4 \mathrm{t} \mathrm{ha}^{-1}$ of lime was added to the soil while tilling and incorporating the $C$. juncea biomass to the soil. The soybean (IAC-FOSCARIM) was sowed in the summer of 1985 and fertilized with 350 $\mathrm{kg} \mathrm{ha}^{-1}$ of 0-28-15 NPK. Same nutrient rate was applied for 1987 and 1988 crop seasons. Soil has been cropped under NTS from that date with annual crops in summer/ winter rotation scheme. The winter crops cultivated from 1985 to 1988 did not receive fertilizers. Yield and soil fertility dataset concerning to 1985, 1987 and 1988 were chosen because in these years the soybean was the summer crop. In 1986, the summer crop was maize. The mean annual rainfall was about 1,293; 1,141; 2,015 and $1,419 \mathrm{~mm}$, respectively in $1984 / 85,1985 / 86,1986 / 87$ and $1987 / 88$ crop seasons.

Soil sampling and analytical determinations. Soil was sampled in 1985, 1987 and 1988 at 63 points on a 20 x $20 \mathrm{~m}$ regular grid (Figure 1) at 0-0.2 m depth.

The samples were air-dried and ground to pass through a $2 \mathrm{~mm}$ sieve. Routine chemical analysis was performed as described by RAIJ and QuAGGIO (1983): $\mathrm{pH}$ was determined in a suspension of soil and 0.01 mol L-1 $\mathrm{CaCl}_{2}$ solution (1:2.5, v/v); organic matter $(\mathrm{OM})$ was determined by ferrous sulfate titration after wet oxidation with $\mathrm{K}_{2} \mathrm{Cr}_{2} \mathrm{O}_{7}+\mathrm{H}_{2} \mathrm{SO}_{4}$; available $\mathrm{K}, \mathrm{Ca}, \mathrm{Mg}$ and $\mathrm{P}$ were extracted with $1 \mathrm{~mol} \mathrm{~L}^{-1} \mathrm{NH}_{4} \mathrm{Cl}$ saturated ionic resin method and analyzed with flame photometry for $\mathrm{K}$, atomic absorption spectrometry for $\mathrm{Ca}$ and $\mathrm{Mg}$ and fotocolorimetry for $\mathrm{P}$; total acidity $(\mathrm{H}+\mathrm{Al})$ was extracted with $0.5 \mathrm{~mol} \mathrm{~L}^{-1}$ calcium acetate $\mathrm{pH} 7$ and determined by titration with $0.5 \mathrm{~mol} \mathrm{~L}^{-1} \mathrm{NaOH}$. Cation exchange capacity (CEC) was determined by summing $\mathrm{K}+\mathrm{Ca}+$ $\mathrm{Mg}+\mathrm{H}+\mathrm{Al}$ content and the base saturation index (BS) was estimated as the proportion of CEC loaded by $\mathrm{K}$ $+\mathrm{Ca}+\mathrm{Mg}$, presented as percentage, and calculated by $\mathrm{BS}=[(\mathrm{K}+\mathrm{Ca}+\mathrm{Mg}) / \mathrm{CEC}] \times 100$. In this paper the data concerning $\mathrm{OM}, \mathrm{H}+\mathrm{Al}, \mathrm{CEC}, \mathrm{BS}$ and soybean yield will be discussed.

Statistical analyses. Exploratory data analyses and normality were tested before statistical analyses $(P=0.05)$ using Kolmogorov-Smirnorv (KS) tests. This was employed also to determine whether there were any outliers in the dataset and the extent of any departure from a normal distribution. Linear correlations were also calculated among soil parameters and soybean yield.

Geostatistical methods are based on the calculation of the experimental semivariograms. Semivariogram calculations were carried out while checking for possible trends in the data sets and if detected, trends were removed by fitting a polynomial surface and working with the residues. Omnidirectional semivariograms were calculated and mathematical models were fitted to the experimental values. The best fit line was selected by cross validation and once a model type was chosen

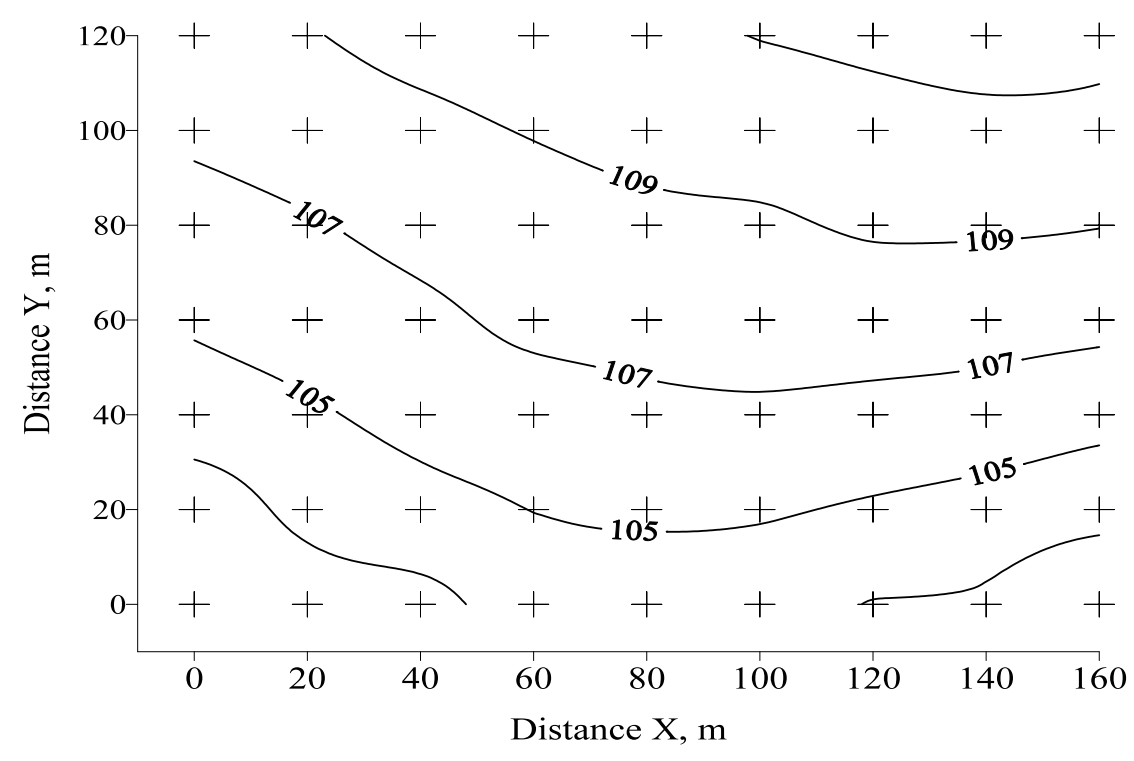

Figure 1. Schematic distribution of sampling points across experimental field plot. Crossed symbols indicates sampling points location and the numbered lines the terrain relative elevation. 
its parameters (nugget effect, sill and range of spatial dependence) were determined using least squares approximation. The spatial dependence degree (SDD) was calculated according with CAMBARDELLA et al. (1994) as the proportion, in percentage, of nugget effect $\left(\mathrm{C}_{0}\right)$ to the sill $\left(\mathrm{C}_{0}+\mathrm{C}_{1}\right)$ and classified as strong $(<25 \%)$, moderate $(25-75 \%)$ and weak $(>75 \%)$.

The semivariogram parameters obtained from the fitted model were used to interpolate values, at unsampled locations over the plot on a grid with an interval of $2 \mathrm{~m}$ using kriging. The optimal number of data points to be incorporated in the interpolation was determined by cross validation. The interpolation variances were also calculated. As geostatistics offers a collection of tools in order to understand and model spatial variability in this paper it was also studied the use of secondary information to improve the predictions given by ordinary kriging. In this case the use of secondary information available at finer spatial resolution than the sampled values of primary target variable results in a more accurate interpolation (GOOVAERTS, 1997; McBratney et al., 2000) and is called cokriging. So, cokriging is an extension of kriging to more than one variable and it is beneficial where the primary variable is underestimated with respect to the secondary variable.

In this research cross-semivariograms were analyzed for the pairs of variables which showed a high level of correlation. Experimental cross-semivariograms were isotropic for directions of $0,45^{\circ}, 90^{\circ}, 135^{\circ}$ and primary and secondary variables were recorded at the same locations. However, it may be more useful to use a reduced form of cokriging, the collocated cokriging (CLCK), especially when working with several variables. The CLCK requires the knowledge of the semivariogram of the primary variable, the crosssemivariogram between the primary and secondary variables and the $C_{0}$ value from secondary variable semivariogram (GOOVAERTS, 1997; REMACRE and BOTELHO, 2005).

All calculations involving geostatistics were performed using the software written with FORTRAN code and presented in VIEIRA et al. (1983) and VIEIRA (2000). Interpolation maps were created using the software SURFER® v.7 (GOLDEN SOFTwARE, 1997).

\section{RESULTS AND DISCUSSION}

The main statistical moments for the general soil properties under study and crop yield are shown in table 1 . The coefficients of skewness $\left(\mathrm{C}_{\mathrm{sk}}\right)$ and kurtosis $\left(\mathrm{C}_{\mathrm{k}}\right)$ and the Kolmogorov-Smirnov normality test confirmed that almost all data followed normal distribution and in this case, mean values truly represents the population those data came from. The exceptions are for CEC_87 (P $<0.01)$ and $\mathrm{Ca}$ _88 $(\mathrm{P}<0.01)$ (Table 1$)$.

Based on the classification criterion proposed by WARRICK and NIELSEN (1980) the variability of these properties are considered to be low $(\mathrm{Cv}<12 \%)$ and medium $(12 \%<\mathrm{Cv}<62 \%)$. For the attributes under study the $\mathrm{Cv}$ values ranged from $10.8 \%$ to $37.8 \%$. Higher values were observed for $\mathrm{Ca}$ and $\mathrm{Mg}$ content for the three periods (Table 1). Some of those $\mathrm{Ca}$ and $\mathrm{Mg}$ content variation may be attributed to soil bioturbation. No tillage system, because it does not revolve the soil surface, contributed to the increase of ants and termites population which was observed visually at the field. In addition HARPSTEAD et al. (1997) indicated that the presence of termites might contribute to the increase in Ca content in localized areas. Also, $\mathrm{Cv}$ for soil OM and BS index decreased from 1985 to 1988 with extremes ranging from $20.4 \%$ to $10.8 \%$ for OM and from $24.4 \%$ to $17.9 \%$ for BS. Further, soil OM and BS index mean values increased $32 \%$ and $21 \%$ in this period, respectively, owing that NTS contributed to the improvement and homogenization of these soil properties. These results were in agreement with the reported in others experiments concerning to NTS adoption (Roth et al.,1991; DUIKER and BEEGLE, 2006). Low to medium $\mathrm{Cv}$ values for soil properties also indicates a low diversity (PAZ-GonZALEZ et al., 2000) and high quality in agricultural practices like fertilizer application and sowing taking in account that $\mathrm{Cv}$ less than $35 \%$ characterize a homogenous data series (VANNI, 1998).

Calcium and $\mathrm{Mg}$ mean content increased from 1985 to 1987 due to lime application. Lime is a low soluble salt and its reaction in the soil is dependent of a series of factors such as lime particle size, soil water content, time, soil buffering capacity, etc. As shown earlier, the 1985/ 86 presented the lowest rainfall $(1,141$ $\mathrm{mm}$ ) for the studied period and this could contribute to the variation on soil Ca and $\mathrm{Mg}$ content. Although BS index showed some increase with time, its mean value were bellow the recommended as adequate for fertile soil under most annual crops (i.e. BS equal to $70 \%$ ) with extremes ranging from slightly above $80 \%$ to a minimum of $25-35 \%$ (Table 1 ).

Table 2 presents the correlation matrix between soil and plant variables. In almost all weathered tropical soil OM content represents the most important source of electrical charges as can be observed by the significant correlation between OM x CEC for 1985. The increase of $\mathrm{Ca}$ and $\mathrm{Mg}$ content, described above, may be invoked to explain the decrease of this correlation verified for 1986 and 1988 considering that CEC were obtained by summing cation content. In this case direct relationship between OM and CEC was not verified. There was a slight decrease for the correlation between Ca $x$ BS in 
Table 1. Exploratory data analyses for some soil attributes at 0-20 cm depth layer and soybean yield in 1985,1987 and 1988 under no tillage system

\begin{tabular}{|c|c|c|c|c|c|c|c|c|}
\hline Variable & Mean & SD & $\mathrm{CV}$ & Min. & Max. & $\mathrm{C}_{\mathrm{Sk}}$ & $\mathrm{C}_{\mathrm{K}}$ & $\mathrm{KS}$ \\
\hline $\mathrm{OM}, \mathrm{g} \mathrm{kg}^{-1}$ & 3.16 & 0.64 & 20.44 & 1.38 & 4.82 & -0.059 & 0.544 & $>0.15$ \\
\hline $\mathrm{Ca}, \mathrm{cmol}_{(+)} \mathrm{kg}^{-1}$ & 0.26 & 0.94 & 36.00 & 0.10 & 0.58 & 1.055 & 1.781 & $>0.15$ \\
\hline $\mathrm{Mg}, \mathrm{cmol}_{(+)} \mathrm{kg}^{-1}$ & 0.80 & 0.30 & 37.84 & 0.30 & 1.70 & 0.668 & 0.186 & $>0.15$ \\
\hline $\mathrm{CEC}, \mathrm{cmol}_{(+)} \mathrm{kg}^{-1}$ & 8.51 & 1.24 & 14.66 & 5.52 & 11.70 & 0.161 & 0.199 & $>0.15$ \\
\hline $\mathrm{BS}, \%$ & 48.09 & 11,72 & 24,36 & 24,76 & 80.34 & 0.354 & -0.044 & $>0.15$ \\
\hline Soybean, $\mathrm{kg} \mathrm{ha}^{-1}$ & $1,149.00$ & 308.50 & 26.80 & 342.40 & 1.952 .00 & 0.115 & 0.456 & $>0.15$ \\
\hline $\mathrm{OM}, \mathrm{g} \mathrm{kg}^{-1}$ & 3.92 & 0.48 & 12.41 & 2.80 & 4.90 & 0.075 & -0.376 & $>0.15$ \\
\hline $\mathrm{Ca}, \mathrm{cmol}_{(+)} \mathrm{kg}^{-1}$ & 3.22 & 0.91 & 28.44 & 1.60 & 6.80 & 1.346 & 3.614 & $>0.15$ \\
\hline $\mathrm{Mg}, \mathrm{cmol}_{(+)} \mathrm{kg}^{-1}$ & 1.38 & 0.45 & 32.85 & 0.50 & 2.60 & 0.334 & -0.085 & $>0.15$ \\
\hline $\mathrm{CEC}, \mathrm{cmol}_{(+)} \mathrm{kg}^{-1}$ & 8.49 & 0.93 & 10.97 & 6.70 & 11.60 & 0.760 & 1.714 & $<0.01$ \\
\hline $\mathrm{BS}, \%$ & 58.37 & 10.50 & 18.09 & 36.00 & 88.00 & 0.342 & 0.302 & $>0.15$ \\
\hline Soybean, $\mathrm{kg} \mathrm{ha}^{-1}$ & $3,135.00$ & 605.90 & 19.30 & $1,917.00$ & 4.500 .00 & 0.224 & -0.476 & $>0.15$ \\
\hline $\mathrm{OM}, \mathrm{g} \mathrm{kg}^{-1}$ & 4.18 & 0.45 & 10.76 & $988-\frac{}{3.20}$ & 5.20 & -0.128 & -0.647 & $>0.15$ \\
\hline $\mathrm{Ca}, \mathrm{cmol}_{(+)} \mathrm{kg}^{-1}$ & 3.11 & 0.94 & 30.28 & 1.30 & 6.20 & 1.232 & 1.783 & $<0.01$ \\
\hline $\mathrm{Mg}, \mathrm{cmol}_{(+)} \mathrm{kg}^{-1}$ & 1.26 & 0.43 & 33.97 & 0.50 & 3.00 & 1.692 & 5.571 & 0.065 \\
\hline $\mathrm{CEC}, \mathrm{cmol}_{(+)} \mathrm{kg}^{-1}$ & 8.19 & 1.05 & 12.82 & 6.10 & 10.80 & 0.672 & 0.112 & $>0.15$ \\
\hline $\mathrm{BS}, \%$ & 58.35 & 10.45 & 17.90 & 34.00 & 81.00 & -0.032 & -0.113 & $>0.15$ \\
\hline Soybean, $\mathrm{kg} \mathrm{ha}^{-1}$ & $2,851.00$ & 498.40 & 17.50 & $1,389.00$ & $3,918.00$ & -0.360 & 0.403 & $>0.15$ \\
\hline
\end{tabular}

$\mathrm{OM}=$ Soil organic matter; $\mathrm{CEC}=$ Cation exchange capacity; $\mathrm{BS}=$ Base saturation index; SD = Mean standard deviation; $\mathrm{CV}=$ Coefficient of variation; $\mathrm{C}_{\mathrm{Sk}}=$ Coefficient of skewness; $\mathrm{C}_{\mathrm{K}}=$ Coefficient of kurtosis; $\mathrm{KS}=$ Kolmogorov-Smirnov's P-value.

Table 2. Correlation coefficients matrix of soil attributes and soybean yield in 1985, 1987 and 1988 under no tillage system

\begin{tabular}{|c|c|c|c|c|c|c|}
\hline & $\mathrm{OM}$ & $\mathrm{Ca}$ & $\mathrm{Mg}$ & CEC & BS & Soybean \\
\hline & & & -1985 & & & \\
\hline $\mathrm{OM}$ & 1.0000 & $0.383^{*}$ & $0.757 *$ & $0.516^{*}$ & $0.328 *$ & $-0.009^{\mathrm{NS}}$ \\
\hline $\mathrm{Ca}$ & - & 1.000 & $0.619 *$ & $0.442 *$ & $0.910 *$ & $-0.120^{\mathrm{NS}}$ \\
\hline $\mathrm{Mg}$ & - & - & 1.000 & $0.495^{*}$ & $0.656^{*}$ & $-0.058^{\mathrm{NS}}$ \\
\hline CEC & - & - & - & 1.000 & $0.191^{\mathrm{NS}}$ & $-0.158^{\mathrm{NS}}$ \\
\hline \multirow[t]{2}{*}{ BS } & - & - & - & - & 1.000 & $-0.079^{\mathrm{NS}}$ \\
\hline & & & -1987 & & & \\
\hline $\mathrm{OM}$ & 1.0000 & $0.124^{\mathrm{NS}}$ & $0.296^{*}$ & $-0.002^{\mathrm{NS}}$ & $0.347 *$ & $-0.128^{\mathrm{NS}}$ \\
\hline $\mathrm{Ca}$ & - & 1.000 & $0.749 *$ & $0.843^{*}$ & $0.502 *$ & $-0.053^{\mathrm{NS}}$ \\
\hline $\mathrm{Mg}$ & - & - & 1.000 & $0.703 *$ & $0.471 *$ & $-0.062^{\mathrm{NS}}$ \\
\hline CEC & - & - & - & 1.000 & $0.023^{\mathrm{NS}}$ & $-0.034^{\mathrm{NS}}$ \\
\hline BS & - & - & - & - & 1.000 & $0.042^{\mathrm{NS}}$ \\
\hline & & & -1988 & 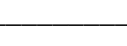 & & . \\
\hline $\mathrm{OM}$ & 1.0000 & $0.196^{\mathrm{NS}}$ & $0.102^{\mathrm{NS}}$ & $0.288^{*}$ & $0.056^{\mathrm{NS}}$ & $-0.054^{\mathrm{NS}}$ \\
\hline $\mathrm{Ca}$ & - & 1.000 & $0.613 *$ & $0.775^{*}$ & $0.850 *$ & $-0.077^{\mathrm{NS}}$ \\
\hline $\mathrm{Mg}$ & - & - & 1.000 & $0.478^{*}$ & $0.797 *$ & $0.048^{\mathrm{NS}}$ \\
\hline CEC & - & - & - & 1.000 & $0.442 *$ & $-0.183^{\mathrm{NS}}$ \\
\hline BS & - & - & - & - & 1.000 & $-0.008^{\mathrm{NS}}$ \\
\hline
\end{tabular}

$\mathrm{OM}=$ organic matter; $\mathrm{Ca}=$ calcium; $\mathrm{Mg}=$ magnesium; $\mathrm{CEC}=$ cation exchange capacity; $\mathrm{BS}=$ base saturation; ${ }^{*}=$ significant $(p<0.05)$ by t-test; ${ }^{\mathrm{NS}}=$ non-significant. 
1985. Because the field was not cultivated for some time, it is possible that $\mathrm{Ca}$ constituted the major cation at that time. This is in agreement with the observed increase in Ca content with time (Table 1).

The mathematical Pearson's correlation index between soil OM and either Ca or Mg decreased (Table 2) probably due to the fact that $\mathrm{OM}$ presented an increasing trend from 1985 and both Ca and Mg increased slowly due to the dissolution of lime with time (Table 1). The weak correlation between OM and soil CEC was also described by Paz-GonZALEz et al. (2000) and, according to these authors, soil cultivation contributes to improve the homogenization of selected soil parameters.

Otherwise, crop yield did not present significant correlation with soil parameters at any time (Table 2). The lack of a significant linear relationship among these variables causes a major restriction for the usefulness of cokriging tools.

The spatial variability was studied by semivariogram calculations. The parameters of the fitted models to the experimental semivariograms are shown in table 3. All semivariograms were fit to spherical models. The goodness of fit can be evaluated also based on the coefficient of determination $\left(R^{2}\right)$.

Some of the models fitted showed very low $\mathrm{R}^{2}$ such as CEC_85 (Table 3). In general the $\mathrm{R}^{2}$ increased with time, and the best fitted model was found for the data referring to the 1988 sampling. Identical trend is shown for the ranges of spatial dependence $(\mathrm{r})$, increasing from 1985 to 1988, but smaller for the 1987 sampling (Table 3). In 1987 the $\mathrm{Mg}$ content showed a pure nugget effect, while Ca_87, CEC_87 and BS_87 exhibited an increase in the values for range of correlation. In general, $\mathrm{Mg}$ showed the worst condition for spatial dependence characterized by the smallest range and poorest model fit, mainly for 1985 and 1987. Also, the semivariogram for OM_87 showed a very well defined trend. The observed trend was removed by fitting a linear or first degree surface to existing data and the calculations were done with the residuals for this variable, OM_res.

Based on the spatial dependence degree (SDD), sill and range values for $\mathrm{OM}$ and $\mathrm{Mg}$, there was a drastic change in the spatial dependence referring to 1987 sampling (Table 3). Moreover, neither the linear trend in $\mathrm{OM}$ nor the pure nugget effect for $\mathrm{Mg}$ conform

Table 3. Semivariograms fit parameters of selected soil properties and soybean yield in 1985, 1987 and 1988 under no tillage system

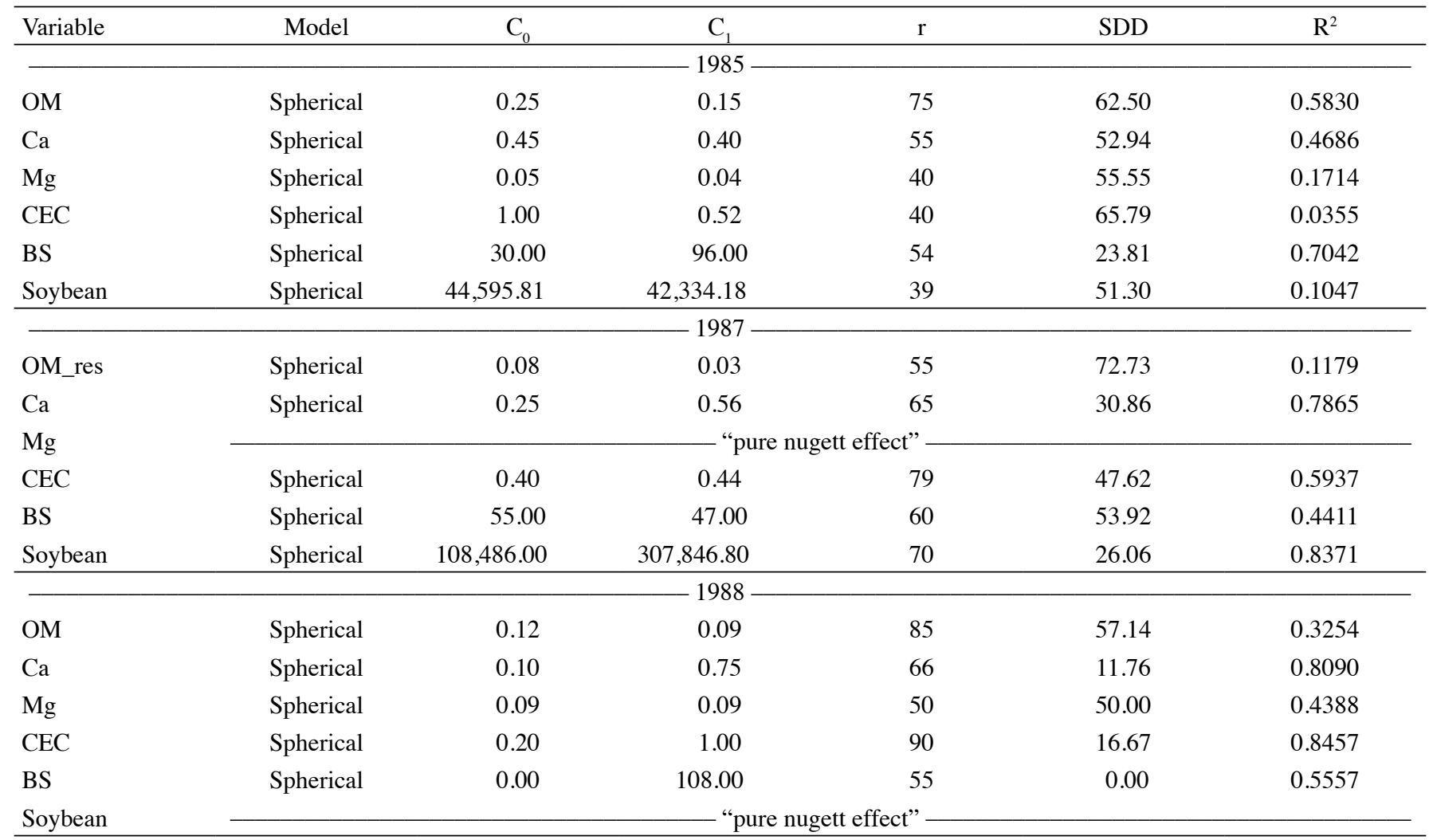

$\mathrm{C}_{0}=$ nugget effect; $\mathrm{C}_{1}=$ structured variance contibution; $\mathrm{r}=$ range; $\mathrm{SDD}=$ Spatial dependency degree; $\mathrm{OM}=$ soil organic matter; $\mathrm{Ca}=$ Calcium; $\mathrm{Mg}=$ Magnesium; OM_res = semivariogram parameters from OM residues fitting model; $\mathrm{BS}=$ base saturation 
very well with the changes that could be imposed by the NTS adoption or the addition of lime. The semivariogram parameters for $\mathrm{Ca}, \mathrm{CEC}$ and for BS are in agreement with the trend expected under no tillage system (Table 3).

This result may be explained by the pronounced increase of SDD values followed by an increase of the range. This implies that the soil became more homogeneous and the uniform regions became larger with time. Both the fertilization and the no tillage system favored this trend.

Crop yield semivariogram could be well determined just for 1985 and 1987 crops (Table 3). A pure nugget effect was considered for 1988. The differences between 1985 and 1987 semivariograms parameters can be explained by the variation on its yield (Table 1). It is reasonable to think that shifting tillage contributed significantly to the difference of almost $173 \%$ on soybean yield comparing data from 1985 taken as reference level (i.e. $100 \%$ ), and 1987.

Burning crop residues, a practice used to clean up the area in 1985, probably altered the microrganisms population with respect to soybean cultivation. Besides that it is important to consider that $\mathrm{N}$ was not used in the fertilization and all requirement of this nutrient were supplied by symbiotic microorganisms. They could not be well established yet in the soil in 1985. The lack of a significant linear correlation of crop yield and soil attributes also may be explained by this condition (DE MARIA et al., 1999).

The correlation between Ca $\times$ BS was the highest in 1985, and there was also some significant correlation for $\mathrm{OM} \times \mathrm{Mg}$ in 1985 and 1987. Weak correlations were observed for the $\mathrm{OM} \times \mathrm{CEC}$ relationship at all investigated periods (Table 2 ) as discussed previously in this paper and it constitutes the major concern leading to not use cross semivariogram for these variables.

Otherwise, for the variables that presented significant correlation between each other the cross semivariograms were examined for the three years analyzed (Table 4). The spatial relationship between $\mathrm{OM} \times \mathrm{Mg}$ and, consequently the reasons for the cross semivariogram calculation, at this point in time are not certain. On the other hand the correlation between OM x Mg decreased from 1985 to 1988 (Table 2). Somewhat similar behavior can be seen in the cross semivariogram parameters, which reflects their spatial relationship (Table 4). The pure nugget effect between $\mathrm{OM} \times \mathrm{Mg}$ for 1988 is maximum for this lack of spatial relationship (Table 4). For Ca $x$ BS the spatial relationship improved with time as can be observed by the decrease of $C_{0}$ values and the maintenance of positive covariance coefficients. Notice that nugget effect values for Ca $\mathrm{x}$ BS decreased from 4 in 1985 to 0 (zero) in 1988.

As shown, crop yield varied about $173 \%$ from 1985 to 1987 and this can be observed by the scale presented in the kriged maps (Figure 2). In both maps the highest yield could be observed near to the area limits in contrast to the center (Figure 2). A reasonable explanation for this behavior can be observed in Figure 3. It describes the spatial variation on BS index and it can be seen that the highest values were observed at the same locations as the crop yield (Figure 3).

The evaluation of three geostatistical interpolation techniques was made for BS index $x$ terrain elevation considering the influence of topography on soil chemical attributes variability (DOBERMANN et al., 1995). Figure 3 shows the maps obtained by ordinary kriging, ordinary cokriging and collocated cokriging, respectively. Ordinary cokriging was applied using the

Table 4. Cross-semivariograms fit parameters of soil attributes in 1985, 1987 and 1988 under no tillage system

\begin{tabular}{|c|c|c|c|c|c|c|c|}
\hline Variable & Model & $\mathrm{C}_{0}$ & $\mathrm{C}_{1}$ & $\mathrm{r}$ & SDD & $\mathrm{R}^{2}$ & Covariance \\
\hline $\mathrm{OM} \times \mathrm{Mg}$ & Spherical & 0.09 & 0.04 & 55 & 69.23 & 0.9919 & 0.146 \\
\hline $\mathrm{Ca} \times \mathrm{BS}$ & Spherical & 4.00 & 5.50 & 60 & 42.10 & 0.5838 & 9.932 \\
\hline OM_res x Mg & Spherical & 0.02 & 0.02 & 70 & 50.00 & 0.2604 & 0.042 \\
\hline $\mathrm{Ca} \times \mathrm{BS}$ & Spherical & 1.00 & 6.00 & 55 & 14.28 & 0.6832 & 6.938 \\
\hline $\mathrm{OM} \times \mathrm{Mg}$ & & & - " pur & $"$ & & & 0.019 \\
\hline $\mathrm{Ca} \times \mathrm{BS}$ & Spherical & 0.00 & 8.00 & 58 & 0.00 & 0.6789 & 8.220 \\
\hline
\end{tabular}

$\mathrm{C}_{0}=$ nugget effect; $\mathrm{C}_{1}=$ structured variance contribution; $\mathrm{r}=$ range; $\mathrm{SDD}=$ spatial dependency degree; $\mathrm{OM}=$ soil organic matter; $\mathrm{Ca}=$ Calcium; $\mathrm{Mg}=$ Magnesium; OM_res = semivariogram parameters from OM residues fitting model; $\mathrm{BS}=$ base saturation . 
topographical heights measured on the same $20 \times 20 \mathrm{~m}$ grid as the secondary variable. The collocated cokriging was built using the topographical height obtained from the digital elevation model in a $2 \times 2 \mathrm{~m}$ grid as the ancillary variable.

The topography in this field is quite uniform with the contour lines almost parallel to the $X$ (horizontal) axis. Three maps are similar in general appearance. The map obtained by ordinary kriging (Figure 3a) shows very smooth contours as a result of the moving average process of kriging (VIEIRA et al., 1983). The map obtained by ordinary cokriging (Figure $3 b$ ) with the topographic height as the secondary variable, reflects the numerical instability (GOOvAERTS, 1997) of the matrix system as shown by the small spots in between large homogeneous areas and by the tortuous contours. The map obtained by collocated cokriging (Figure 3c), although similar to the others, does not have the numerical instability

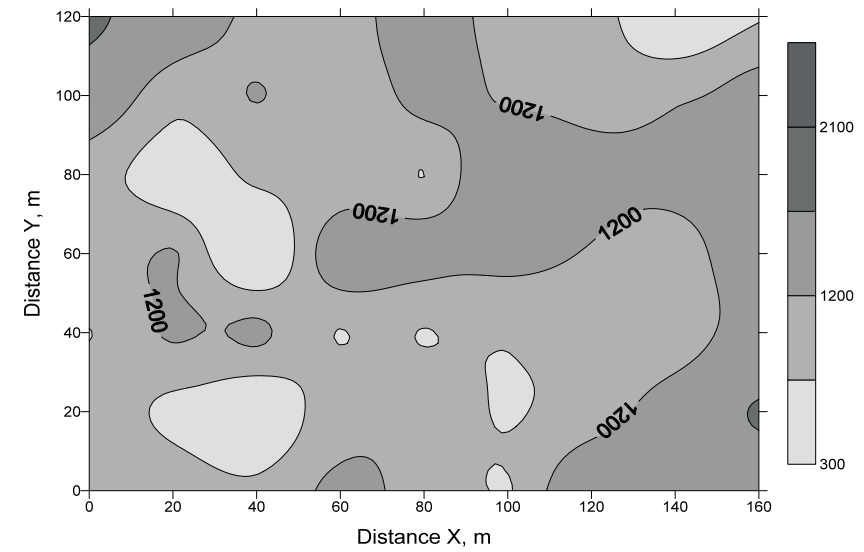

(a)

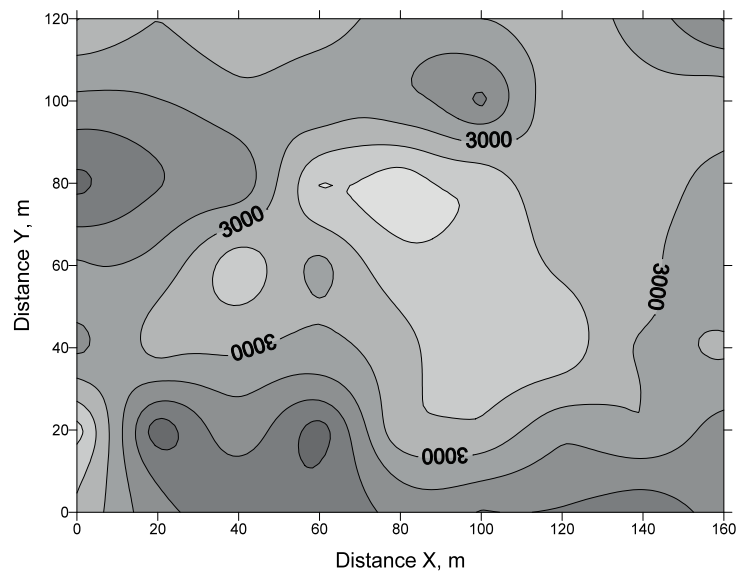

(b)

Figure 2. Soybean yield maps under no tillage system in 1985 (a) and 1987 (b) obtained by ordinary kriging. effects during calculation and shows a little more details than the others. The simplicity involved in this interpolation and the results obtained show that it may be appropriated for local estimation. Besides that, the estimation variances were slightly smaller
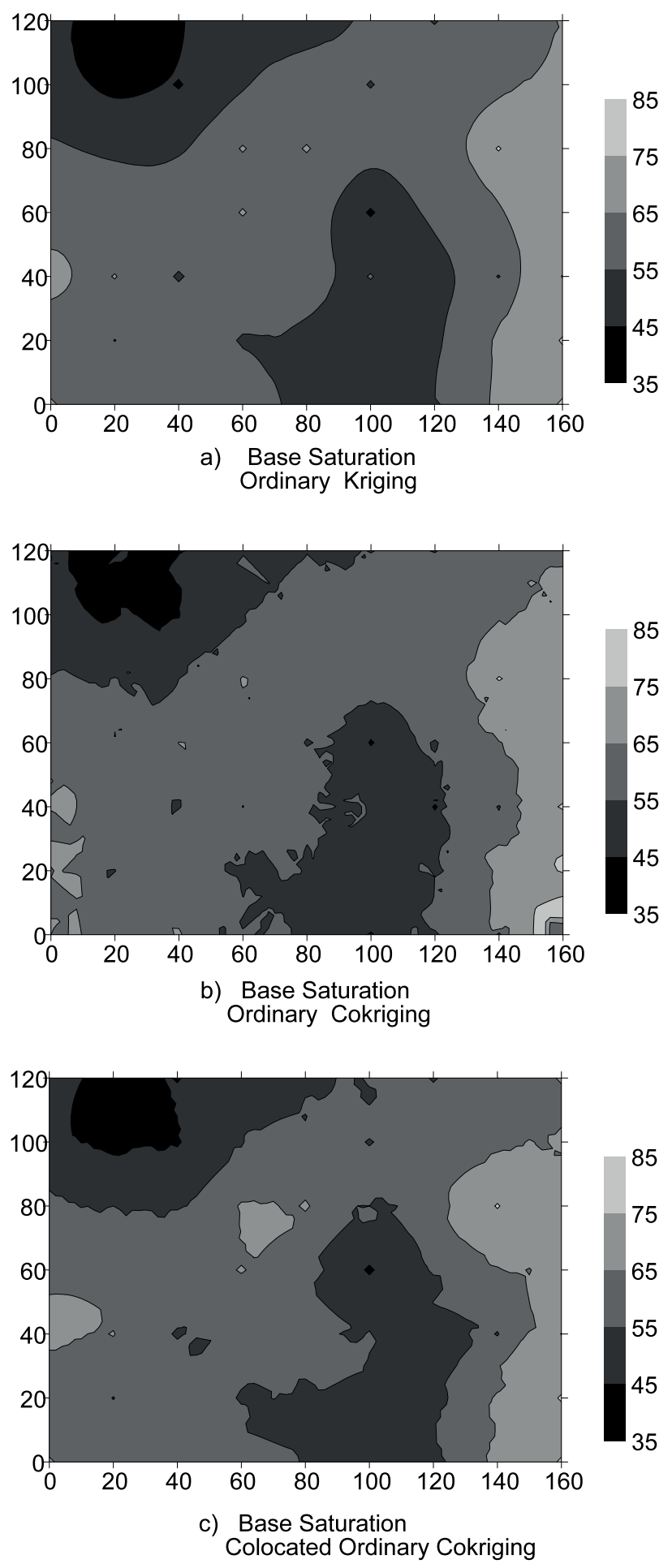

Figure 3. Base saturation maps using kriging (a), ordinary cokriging (b) and colocated ordinary cokriging (c) as interpolation method. 
for the collocated cokriging as compared to the other interpolation methods used.

\section{CONCLUSIONS}

1. The adoption of NTS leads to homogenization of soil parameters after two years.

2. The bivariate kriging method, collocated cokriging with terrain elevation as ancillary information is appropriate to map soil attributes with high detail level in comparison to ordinary kriging and ordinary cokriging.

\section{REFERENCES}

AINA, P.O.; LAL, R.; ROOSE, E.J. Tillage methods and soil and water conservation in West Africa. Soil and Tillage Research, v.20, p.165-186, 1991.

ALVES, M.C.; VIEIRA, S.R.; CASTRO, O.M.; LOMBARDI NETO, F. Effects of crop rotation systems with no tillage in the physical properties of a Latossolo Roxo. In: World Congress of Soil Science, 15. 1994. Acapulco. Abstracts... Acapulco: International Soil Science Society, 1994. p.147-148.

BECKETT, P. H. T. Spatial variability of K-status. In: Proceedings of the 20th colloqium International Potash Institute, 20., 1987. Bern. Proceedings... Bern: International Potash Institute, 1987. p.357-380.

BRENK, C.; PASDA, G.; ZERULLA, W. Nutrient mapping of soils. A suitable basis for site-specific fertilization. In: Stafford, J.V. (Ed.). European Conference on Precision Agriculture, 2., 1999. Odense: Shefield Academic Press, 1999. p.49-59.

CAMBARDELLA, C.A.; MOORMAN, T.B.; NOVAK, J.M.; PARKIN, T.B.; KARLEN, D.L.; TURCO, R.F.; KONOPKA, A.E. Field-scale variability of soil properties in Central Iowa Soils. Soil Science Society of America Journal, 58, p.1501-1511, 1994.

DE MARIA, I.C.; NNABUDE, P.C.; CASTRO, O.M. Long-term tillage and crop rotation effects on soil chemical properties of a Rhodic Ferralsol in southern Brazil. Soil and Tillage Research, v.51, p.69-77, 1999.

DOBERMAN, A.; GOOVAERTS, P.; GEORGE, T. Sources of soil variation in an acid Ultisol of the Philipines. Geoderma, v.68, p.173-191, 1995.

DUIKER, S.W.; BEEGLE, D.B. Soil fertility distributions in long-term no-till, chisel/disk and moldboard plow/disk systems. Soil and Tillage Research, v.88, p.30-41, 2006.

EMBRAPA. Sistema Brasileiro de Classificação de Solos. 2.ed. Rio de Janeiro: Embrapa Solos, 306p. 2006.

GOLDEN SOFTWARE. Surfer for Windows - User's guide. Golden: Golden Software Inc. 501p. 1997.
GOOVAERTS, P. Geostatistics for natural resources evaluation: Applied Geostatistics Series. New York: Oxford University Press, 1997. 500p.

HARPSTEAD, M.I.; SAUER, T.J.; BENNET, W.F. Soil science simplified. Ames: Iowa State University Press, 1997. 210p.

HOSKINSON, R. L.; HESS, J. R.; ALESSI, R. S. Temporal changes in the spatial variability of soil nutrients. In: Stafford, J.V. (Ed.). European Conference on Precision Agriculture, 2. 1999. Odense: Shefield Academic Press, 1999. p.61-70.

MAPA, R.; KUMARAGAMAGE, D. Variability of soil properties in a tropical Alfisol used for shifting cultivation. Soil Technology, v.9,p.187-197, 1996.

MCBRATNEY, A.B.; ODEH, I.O.A.; BISHOP, T.F.A.; DUNBAR, M.S.; SHATAR, T.M. An overview of pedometric techniques for use in soil survey. Geoderma, v.97, p.293- 327, 2000.

OLIVER, M.A.; WEBSTER, R. Statistical methods in soil and land resource survey. Oxford: Oxford University Press, 1990, $316 \mathrm{p}$.

PAZ-GONZALEZ, A.; VIEIRA, S.R.; TABOADA CASTRO, M.T. The effect of cultivation on the spatial variability of selected properties of an umbric horizon. Geoderma, v.97, p.273-292, 2000.

RAIJ, B.; QUAGGIO, J.A. Métodos de análise do solo para fins de fertilidade. Campinas: Instituto Agronômico. 31p. 1983 (Boletim Técnico 81)s

REMACRE, A.Z.; BOTELHO, M.C. O uso da cokrigagem colocada (collocated cokriging) na integração de dados químicos e mineralógicos no minério de ferro. Revista Escola de Minas, v.58, p.61-69, 2005.

ROTH, C.H.; CASTRO FILHO, C, MEDEIROS, G.B. Análise de fatores físicos e químicos relacionados com a agregação de um Latossolo Roxo Distrófico. Revista Brasileira de Ciência do Solo, v.15, p.241-248, 1991.

SOUZA, L.S.; COGO, N.P.; VIEIRA, S.R. Variabilidade de propriedades físicas e químicas do solo em um pomar cítrico. Revista Brasileira de Ciência do Solo, v.21, p.367-372. 1997.

SOIL SURVEY STAFF. Keys to soil taxonomy. 6.ed. Washington: USDA Natural Resources Conservation Service, US Government Printing Office, 1994. 306p.

TRANGMAR, B.B.; YOST, R.S.; UEHARA, G. Application of geostatistics to spatial studies of soil properties. Advances in Soil Science, v.38, p.45-94, 1985.

VANNI, S.M. Modelos de regressão: Estatística aplicada. São Paulo: Legmar Informatica, 1998. 177p.

VIEIRA, S.R. Uso de geoestatística em estudos de variabilidade espacial de propriedades do solo. In: NOVAIS, R.F. (Ed.) 
Tópicos em Ciência do Solo. Viçosa: Sociedade Brasileira de Ciência do Solo, 2000. v.1, p.3-87.

VIEIRA, S.R.; HATFIELD, D.J.L.; NIELSEN, D.R.; BIGGAR, J.W. Geostatistical theory and application to variability of some agronomical properties. Hilgardia, v.51, p.1-75, 1983.

VIEIRA, S.R.; NIELSEN, D.R.; BIGGAR, J.W.Spatial variability of field-measured infiltration rate. Soil Science Society of America Journal, v.45, p.1040-1048, 1981.
WARRICK, A.; NIELSEN, D.R. Spatial variability of soil physical properties in the field. In: HILLEL, D. (Ed.). Applications of soil physics. New York: Academic Press, 1980. p.319-344.

XU, W.; TRAN, R.; SRISVASTAVA, M.; JOURNEL, A. Integrating seismic data in reservoir modeling: The collocated cokriging alternative. In: Annual Technical Conference of the Society of Petroleum Engineers, 67. Abstracts..., Washington: SPE \# 24742, 1992. p.833-842. 